atoms and the 3-connected $\mathrm{O}$ atoms of the $\mathrm{Pt}_{3} \mathrm{O}_{4}$ net, respectively.

The void defined by $\left\{\left[\mathrm{Fe}(\mathbf{L})_{3}\right]_{4} \mathrm{Na}_{3}\right\}^{11+}$ corresponds to $60.4 \%$ of the total unit cell volume (ca. $8475 \AA^{3}$ ). It is filled with $11 \mathrm{ClO} 4$ counterions, 7 additional $\mathrm{Na}^{+} \mathrm{ClO}_{4}$ guest ion pairs, and 9 disordered $\mathrm{H} 2 \mathrm{O}$ molecules. The $\mathrm{H} 2 \mathrm{O}$ molecules interact with each other via weak $\mathrm{H}$ bonds $[d(\mathrm{O},, \mathrm{O})$ ) $2.939(3) \AA]$ and form well-separated, ca. $7 \AA$, $\left[\mathrm{H}_{2} \mathrm{O}\right]_{4}$ square units. The additional $\mathrm{Na}+$ cations belong to two different crystallographic sites, namely, $\mathrm{Na}(2)$ and $\mathrm{Na}(3)$. The $\mathrm{Na}(2)$ atoms define, together with $\mathrm{Na}(1)$, a regular truncated octahedron $[d(\mathrm{Na}(1),,, \mathrm{Na}(2)))$ 8.353(3) $\AA]$, with the $\mathrm{Fe}^{\mathrm{II}}$ atoms placed at the center of the hexagonal. The space inside this sodalite-like, positively charged surface is filled with a symmetrical negatively charged "cage", made up of two nonequivalent perchlorate groups.

The polymer is loaded with $14 \mathrm{Na}^{+} \mathrm{ClO}_{4}^{-}$guest pairs and $18 \mathrm{H}_{2} \mathrm{O}$ molecules per unit cell, which stabilize its structure. Interestingly, the charge distribution in the unit cell is rather singular because it can be described like a "Russian nested doll": the positively charged sodalite-like cage "enclathrate", a negative surface defined by the interpenetration of a cuboctahedron

\section{MS19 P19}

The Melting Point Behaviour in the Short -Chain nAlkan-1-ols Laura Spix, Roland Boese*, Institut für Anorganische Chemie, Universität Duisburg-Essen, Universitätsstr. 5- 7, D-45117 Essen, Germany.

E-mail: roland.boese@uni-due.de

\section{Keywords: alcohols, crystal structure, melting point alternation}

$n$-Alkanes and most of their $\alpha$ - and $\alpha, \omega$-substituted derivatives show a remarkable alternation in their melting points. ${ }^{[1,2]}$ Usually, representatives with an even number of $\mathrm{C}$-atoms melt relatively higher than those with an odd number. Other physical properties such as solubilities and sublimation enthalpies that are related to the solid state also exhibit an alternating pattern, whereas those related to the liquid state show monotonic behavior. ${ }^{[3,4-7]}$ But there also exist exceptions. For instance the series of the 1chloro-, 1-bromo-, and 1-thioalkanes show an inverted alternancy of the melting points ${ }^{[8]}$ and the 1 -alcohols are almost monotonic. It was shown that the melting points in $\alpha, \omega$-alkanediols are correlated to the calculated lattice energies. ${ }^{[5]}$ In this study, single crystals of six members of $n$-alkane-1-ols $\left(\mathrm{CH}_{3}-\left(\mathrm{CH}_{2}\right)_{n}\right.$-OH, $\left.n=4-9\right)$ have been grown in situ using a miniature zone melting procedure, and their X-ray analyses have been performed. The structural similarities and differences between even and odd members could be analyzed by the packing arrangements and by the interplay between hydrogen bonding and van der Waals interaction, however the calculated packing energies exhibit a stronger alternation behavior than the melting points.

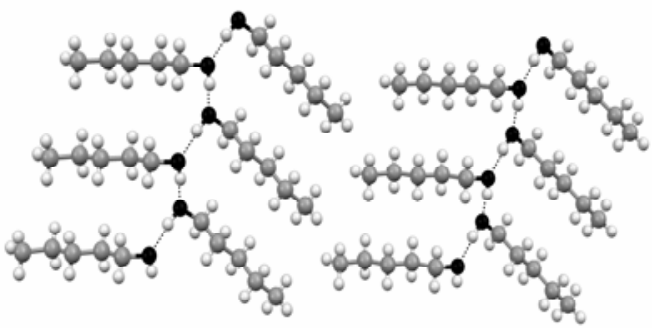

Figure 1: Crystal structure of n-pentane-1-ol

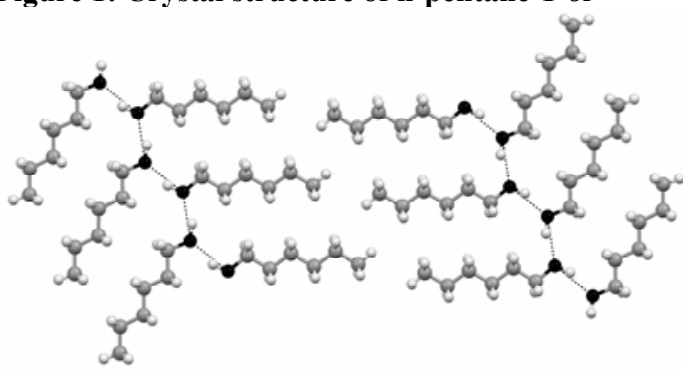

Figure 2: Crystal structure of n-hexane-1-ol

[1] A. Baeyer, Ber. Chem. Ges. 1877, 10, 1286 -1288.

[2] A. Kitaigorodskii, Molecular Crystals and Molecules, Academic Press, 1973.

[3] F. L. Breusch, Fortschr. Chem. Forsch. 1969, 12, 119 - 184.

[4] R. Boese, H.-C. Weiss, D. Bläser, Angew. Chem. Int. Ed. 1999, 38, 988-992.

[5] V. R. Thalladi, R. Boese, H.-C. Weiss, Angew. Chem. Int. Ed. 2000, 39, 918-922.

[6] V. R. Thalladi, R. Boese, H.-C. Weiss, J. Am. Chem. Soc., 2000, 122, 1186-1190.

[7] V. R. Thalladi, M. Nüsse, R. Boese, J. Am. Chem. Soc., 2000, 122, 9227-9236.

[8] R. Boese, H.-C. Weiss, V. R. Thalladi, C. Schauerte Durban, ECM21, Book of Abstracts, 2003 